\title{
Preparation of Electrochemical Biosensor for Detection of Organophosphorus Pesticides
}

\author{
Ashish Gothwal, ${ }^{1}$ Puneet Beniwal, ${ }^{1}$ Vikas Dhull, ${ }^{2}$ and Vikas Hooda ${ }^{1}$ \\ ${ }^{1}$ Centre for Biotechnology, Maharshi Dayanand University, Rohtak 124001, India \\ ${ }^{2}$ Department of Bio- \& Nanotechnology, Guru Jambeshwar University of Science \& Technology, Hisar 125001, India \\ Correspondence should be addressed to Vikas Hooda; vikas.cbtmdu@gmail.com
}

Received 8 September 2014; Accepted 10 December 2014; Published 24 December 2014

Academic Editor: Teizo Kitagawa

Copyright (C) 2014 Ashish Gothwal et al. This is an open access article distributed under the Creative Commons Attribution License, which permits unrestricted use, distribution, and reproduction in any medium, provided the original work is properly cited.

\begin{abstract}
Polyvinyl chloride (PVC) can be used to develop reaction beaker which acts as electrochemical cell for the measurement of OP pesticides. Being chemically inert, corrosion resistant, and easy in molding to various shapes and size, PVC can be used for the immobilization of enzyme. Organophosphorus hydrolase was immobilized covalently onto the chemically activated inner surface of PVC beaker by using glutaraldehyde as a coupling agent. The carbon nanotubes paste working electrode was constructed for amperometric measurement at a potential of $+0.8 \mathrm{~V}$. The biosensor showed optimum response at $\mathrm{pH} 8.0$ with incubation temperature of $40^{\circ} \mathrm{C} . K_{m}$ and $I_{\max }$ for substrate (methyl parathion) were $322.58 \mu \mathrm{M}$ and $1.1 \mu \mathrm{A}$, respectively. Evaluation study showed a correlation of 0.985 , which was in agreement with the standard method. The OPH biosensor lost $50 \%$ of its initial activity after its regular use for 25 times over a period of 50 days when stored in $0.1 \mathrm{M}$ sodium phosphate buffer, $\mathrm{pH} 8.0$ at $4^{\circ} \mathrm{C}$. No interference was observed by interfering species.
\end{abstract}

\section{Introduction}

Organophosphate (OP) compounds are used as pesticides and insecticides in agriculture and have found applications in military practices as chemical warfare agents. OP compounds contribute about $38 \%$ of the total pesticides used worldwide [1]. Commonly used OP pesticides include parathion, malathion, methyl parathion, chlorpyrifos, diazinon, dichlorvos, phosmet, and fenitrothion. According to World Health Organization reports, there are three million pesticide poisonings that occurred worldwide every year; most of them are OP-related, and 200,000 deaths occur due to either self-poisoning or occupational exposure [2]. Reports in the literature demonstrate that OP pesticides affect the nontarget organisms such as birds and fish, as well as humans through exposure to water resources, fruits, vegetables, and processed foods contaminated by OP pesticides. The OP pesticides irreversibly inhibit the activity of acetylcholine esterase, an enzyme essential for the proper functioning of the central nervous system in humans and insects, resulting in the accumulation of the neurotransmitter acetylcholine in the nerve cells and interfere with muscular responses and cause serious problems and sometimes fatal [3-5]. Analytical methods for determination of these toxic compounds are required to ensure that environment and human health will not be compromised by the usage of OP pesticides. There are many laboratory based analytical methods which are commonly used for the determination of OP pesticides. These include gas chromatography (GC), high-performance liquid chromatography (HPLC), capillary electrophoresis $[6,7]$, mass spectrometry [8], and thermospray-mass spectrometry [9]. Besides the sensitivity and accuracy of these methods, they are expensive and time-consuming and require pretreatment of the sample, as well as requiring highly trained persons to perform them, and are not suitable for in-field analysis $[8,10,11]$.

The need for rapid and cost-effective analytical methods for field analysis of OP pesticides has developed many techniques, in which few of them are bioanalytical in nature. These techniques are based on the inhibition assay [12] and immunoassay [13]. Enzyme-linked immunosorbent assay (ELISA) is quite sensitive assay for OP pesticides but, like other immunoassays, can detect only single compound and require multiple time-consuming steps. Inhibition assays 
based on cholinesterase activity are also used for screening processes. But these methods are not well suited for process control monitoring assays where fast and repetitive analyses are required [14].

These problems can be solved by the use of biosensor technology which fulfils the demands for on-site monitoring and the rapid detection of neurotoxic agents [15]. Biosensors based on the acetylcholine esterase (AChE) inhibition have been widely used for the determination of OP pesticides [16]. The main drawback of inhibition-based biosensors involves multiple-step operation, such as time-consuming incubation and reactivation/regeneration steps [14, 17].

Organophosphorus hydrolase $(\mathrm{OPH})$ can catalyze the hydrolysis of a large number of OP pesticides [18]. The enzymatic hydrolysis of $\mathrm{OP}$ pesticides involves a $\mathrm{pH}$ change, as well as the generation of chromophoric species [19]. OPHbased assays are direct and respond to OP pesticides as substrate rather than inhibitors in case of inhibition-based biosensors. Consequently, these assays can be reversible and require only target analyte [14]. The main problem associated with these methods involves the use of free enzyme which can be used once and also increases the cost of procedure. To overcome this problem, use of immobilization method for confining the enzyme molecules onto the different insoluble supports, this enhances the reusability of enzyme through immobilization.

Although OPH-based methods have several advantages such as selectivity for target analyte and show fast response, they are less sensitive and have low detection limits as compared to inhibition-based methods [20,21].

These problems can be overcome by using the carbon nanotubes (CNTs) as transducer material in amperometric biosensors. CNT showed excellent electrocatalytic properties with larger surface area [22]. Deo et al., which significantly enhanced the amperometric signals generated from OP pesticides [23]. The OPH biosensors provide a simple, fast, accurate, and selective monitoring of OP pesticides, as well as being good for in-field applications and monitoring of detoxification processes [19].

In the present method, the $\mathrm{OPH}$ was extracted and purified from Brevundimonas diminuta cells and used for the development of electrochemical biosensor by covalent immobilization of enzyme on to polyvinyl chloride (PVC) surface rather than working electrode. This facilitates the opportunity to change the working electrode on deterioration, without wasting the immobilized enzyme which makes it economical and convenient. The use of carbon nanotubes for the construction of working electrode provides efficient charge transfer from one phase to another. The use of polyvinyl chloride (PVC) in bioanalytical techniques will open a new pathway in biosensor design and fabrication, diagnostic kits, and related biomedical instrumentation.

\section{Materials and Methods}

2.1. Chemicals and Reagents. Sephadex G-100 was purchased from MP Biomedicals. Nutrient broth, tris-HCL, EDTA, lysozyme, sucrose, and sodium hydroxide were purchased from Himedia. Glutaraldehyde (grade 1.25\%) was purchased from Sigma chemicals, and organophosphorus (OP) pesticide (methyl parathion) was purchased from Shri Ram Fertilizers \& Chemicals. All other chemicals were of analytical reagent grade unless otherwise stated. Double distilled water (DDW) was used throughout the experiments. Silver wire and PVC (polyvinyl chloride) beaker were bought from local market.

2.2. Instruments and Equipment. Cyclic voltammetry (CV) measurements were performed on a potentiostat/galvanostat (PGSTAT12/30/302, Autolab) with a three-electrode system composed of a platinum (Pt) wire as an auxiliary electrode, an $\mathrm{Ag} / \mathrm{AgCl}$ electrode as reference electrode, and carbon nanotubes paste based working electrode. UV spectrophotometer (Shimadzu Corporation, Japan), temperature controlled water bath (SunRon), digital pH meter (EUTECH), refrigerator (LG), microwave oven (LG), rotatory incubator shaker (HICON), magnetic stirrer (HICON), refrigerated centrifuge (SIGMA), and deep freezer (Voltas). The study of surface morphology was carried out with scanning electron microscope (SEM) (Model Joel JSM-6510, Japan) at Department of Chemistry, M. D. University, Rohtak, India.

2.3. Microorganism. The lyophilized sample of bacteria Brevundimonas diminuta (MTCC 3361) was purchased from IMTECH, Chandigarh.

2.4. Revival and Growth of Bacteria. Lyophilized sample of B. diminuta was mixed with $5 \mathrm{~mL}$ of nutrient broth (pH-8.0) in a test tube to make a bacterial suspension. The conical flask $(250 \mathrm{~mL})$ containing $100 \mathrm{~mL}$ nutrient broth (pH-8.0) was inoculated with bacterial suspension. The culture media were incubated in a rotatory incubator shaker at $200 \mathrm{rpm}$ for 24 hours at $30^{\circ} \mathrm{C}$. Growth of bacteria was checked by taking O.D. at $600 \mathrm{~nm}$.

2.5. Extraction and Purification of OPH from Brevundimonas diminuta. After desirable growth, the cells were centrifuged at $8000 \mathrm{rpm}$ for 10 minutes. The cell pellets was incubated with $0.75 \mathrm{M}$ Sucrose, mixed in $7.5 \mathrm{~mL}$ of $50 \mathrm{mM}$ Sodium Phosphate Buffer, $\mathrm{pH} 8$ at $20^{\circ} \mathrm{C}$ for 10 minutes. The suspension war treated with lysozyme as described by Herzliger et al. 1984 [24]. the suspension was centrifuged at $10000 \mathrm{rpm}$ for 5 minutes. The pallet was separated and re-suspended in $20 \mathrm{~mL}$ of $50 \mathrm{mM}$ sodium phosphate buffer $(\mathrm{pH} 8)$ containing $50 \mathrm{mM}$ $\mathrm{NaCl}$ at $4^{\circ} \mathrm{C}$ for one hour with constant steering [25]. After centrifugation at $10000 \mathrm{rpm}$ for 5 minutes the supernatant was separated and treated as crud enzyme solution. The crude solution was concentrated using lyophilization machine. Purification of concentrated crude Organophosphate hydrolase was done using sephadex G-100 column $(2.5 \times 30 \mathrm{~cm})$ as described by Liu et. al. 2004 [26].

2.6. Enzyme Assay and Protein Estimation. The $0.1 \mathrm{~mL}$ of purified Organophosphate hydrolase enzyme solution was mixed with 2.9 mL Sodium Phosphate Buffer ( $\mathrm{pH} 8$ ), $5 \mathrm{nM}$ methyl parathion $(0.1 \mathrm{~mL})$ was added to the enzyme solution 


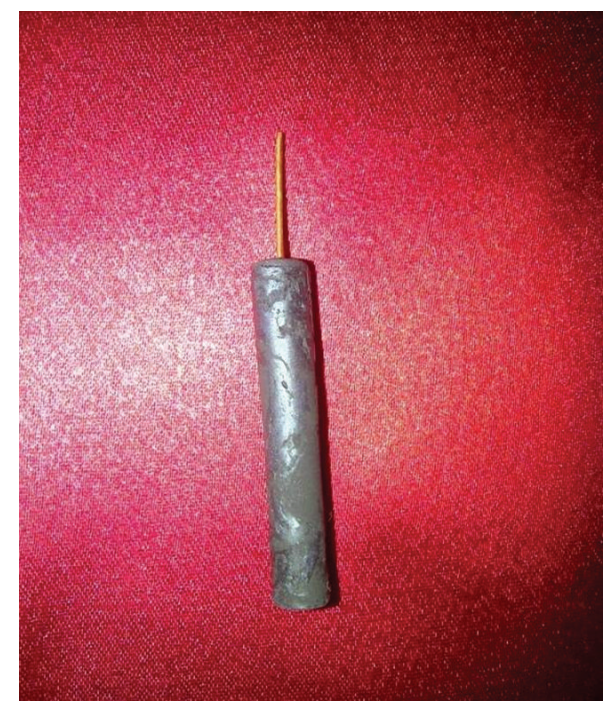

FIGURE 1: Carbon nanotubes paste working electrode.

and incubated at room temperature for 10 minutes. The spectrophotometric reading of the assay was taken at $410 \mathrm{~nm}$ [27]. The total protein content of the purified Organophosphate hydrolase enzyme solution was measured by Lowery method [28].

OP pesticide $+\mathrm{H}_{2} \mathrm{O} \stackrel{\text { OPH }}{\longrightarrow}$ 4-nitophenol + diethyl phosphate

$$
(\lambda=410 \mathrm{~nm})
$$

2.7. Covalent Immobilization of OPH onto Inner Surface of PVC Beaker. Covalent immobilization of organophosphorus hydrolase onto PVC beaker surface was done by using the method described by Hooda et al. [29]. Inner surface of PVC beaker was filled with $5 \mathrm{~mL}$ of enzyme solution and kept overnight at $4^{\circ} \mathrm{C}$. The surface was washed with buffer to remove the unbound enzyme. The reaction beaker was stored at $4^{\circ} \mathrm{C}$ containing sodium phosphate buffer (50 mM, pH-8.0).

2.8. Scanning Electron Microscopy of PVC Surface. To confirm the immobilization of enzyme, the scanning electron microscopic (SEM) study of the surface of PVC beaker was carried out, before and after enzyme immobilization at Department of Chemistry, M. D. University, Rohtak, India.

\subsection{Preparation of Carbon Nanotubes Paste Working Elec-} trode. Carbon nanotubes powder $(1.0 \mathrm{~g})$ and $\mathrm{NH}_{4} \mathrm{Cl}(0.2 \mathrm{mg})$ were mixed with paraffin oil in a ratio to obtain the consistency of paste [29]. This paste was filled in a plastic hollow tube $(2 \mathrm{~cm}$ length and $4 \mathrm{~mm}$ diameter) with one closed end. Electrical contact was made by inserting a silver wire into the carbon nanotubes paste at one end (Figure 1). This formed the body of the working electrode. The surface of the electrode was washed with buffer and stored at $4^{\circ} \mathrm{C}$ when not in use. surements. An amperometric OPH biosensor was developed

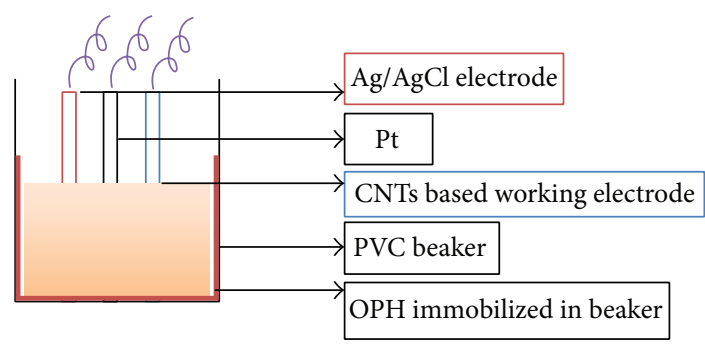

FIgURE 2: Basic assembly of OPH biosensor.

by using enzyme immobilized PVC reaction beaker along with the three electrodes, that is, carbon nanotubes paste as working electrode, $\mathrm{Ag} / \mathrm{AgCl}$ electrode as reference, and Pt wire as auxiliary electrode and being connected through potentiostat/electrochemical analyzer (Figure 2).

The electroanalytical measurements for OP pesticides were performed using a potentiostat/electrochemical analyzer. The cyclic voltammetric study of 4-nitrophenol was done in $50 \mathrm{mM}$ sodium phosphate buffer ( $\mathrm{pH}-8.0)$ in a reaction beaker cell at room temperature. In the cyclic voltammetry experiments, the scan rate was $50 \mathrm{mV} / \mathrm{sec}$ and the scan range was $0 \mathrm{~V}$ to $+1.0 \mathrm{~V}$.

2.11. Kinetic Properties of Immobilized OPH-Based Biosensor. The following kinetic properties of $\mathrm{OPH}$ biosensor were studied: optimum $\mathrm{pH}$, incubation temperature, time of incubation, effect of substrate (methyl parathion) concentration, and calculation of $K_{m}$ and $I_{\max }$ from Line weaver - Burk plot between reciprocal of substrate concentration $(1 /[S])$ and reciprocal of amount of the current $(1 /[I])$.

2.12. Evaluation of the Present Method. The evaluation of present method was carried out by studying its linearity, minimum detection limit, analytical recovery, precision, and accuracy. The effect of interfering species on the response of biosensor was studied. The storage stability and reusability of present method were also determined.

2.12.1. Linear Working Range and Minimum Detection Limit. The linearity and minimum detection limit were calculated by correlating the values with standard graph.

2.12.2. Analytical Recovery. To determine the reliability of the method, different concentrations of methyl parathion (5 and $10 \mu \mathrm{M})$ were added to the samples and the mean analytical recovery was determined by the present method.

2.12.3. Precision. To study the reproducibility of the present method, the OP pesticide level was determined in the sample on the same day (within batch) and in the same sample after storage at $4^{\circ} \mathrm{C}$ for one week (between batch), coefficients of variation $(\mathrm{CVs})$ were calculated for the present method.

2.12.4. Accuracy. To evaluate the accuracy of present method, the levels of methyl parathion in 5 spiked water samples were 
determined by the present method and compared with those obtained by standard method.

2.12.5. Reusability and Storage Stability of the Present Method. Before reuse of the OPH biosensor, it was washed by washing buffer $(0.01 \mathrm{M}$ phosphate buffer saline, $\mathrm{pH}-7.2$ with $0.1 \%$ tween 20). The storage stability of the present biosensor was investigated over a period of two months, when reaction beaker was stored at $4^{\circ} \mathrm{C}$. The response of present method was measured once in every 5 days.

2.12.6. Effect of Interfering Species. The amperometric response was also checked in the presence of potential interfering species such as glucose, fructose, and sucrose as well as metal ions ( $\mathrm{Zn}$ (II), $\mathrm{Cu}$ (II), Cd (II), $\mathrm{Ni}$ (II), and $\mathrm{Pb}$ (II)) each at a concentration of $2 \mu \mathrm{M}$.

2.13. Application of Newly Developed OPH Biosensor. The water and food samples prone to be contaminated with OP pesticides determination were taken for study. Water samples which are used for the drinking purpose were used directly for the determination of OP pesticides. The food samples, that is, vegetables and fruits, (cauliflower, cabbage, grapes, and apple) were bought from local market. The food samples were washed with distilled water and chopped. 100 grams of each chopped sample was crushed in pestle mortar and homogenize with $50 \mathrm{~mL}$ of PBS ( $\mathrm{pH} 7.0$ ) and stirred for $1 \mathrm{~h}$ at room temperature. The samples were filtered through filter paper and centrifuged at $8000 \mathrm{rpm}$ for $8 \mathrm{~min}$. Supernatant was collected and take $20 \mathrm{~mL}$ of supernatant for OP pesticide measurements.

OP compounds present in the sample were hydrolyzed to 4-nitrophenol by the $\mathrm{OPH}$ enzyme immobilized onto PVC surface. Optimum potential was applied to oxidize 4nitrophenol and the response current generated was directly proportional to the OP compound concentration in the sample. This electrochemical technique is employed to determine OP pesticide concentration in food and water samples.

\section{Results and Discussion}

3.1. Purification of Organophosphorus Hydrolase from Brevundimonas diminuta. Enzyme was purified from crude extract by gel filtration on Sephadex G-100 and ion exchange chromatography on DEAE-sepharose. The enzyme was purified by 14.15 -fold to a specific activity of $20.81 \mathrm{U} / \mathrm{mg}$ of protein from the crude OPH solution with a yield of $19.92 \%$. The purified enzyme showed a single band at $36 \mathrm{KDa}$ on SDS-PAGE.

3.2. Covalent Immobilization of OPH onto PVC Surface. Covalent immobilization of enzyme on PVC beaker surface was carried out by method described previously [29]. Inner surface of PVC beaker $(30 \mathrm{~mL})$ capacity was treated with $2 \mathrm{~mL}$ of fuming nitric acid at $30^{\circ} \mathrm{C}$ for about $2 \mathrm{~h}$. After that PVC beaker was washed first with running tap water and then with double distilled water. The surface was then treated with $1 \mathrm{~mL}$ of methyl cyanide for $1 \mathrm{~h}$ and thereafter with concentrated $\mathrm{HCl}(1 \mathrm{~mL})$ for $2 \mathrm{~h}$. The activated surface of PVC was rinsed with distilled water and incubated with $1.25 \%(\mathrm{w} / \mathrm{v})$ glutaraldehyde for about $8 \mathrm{~h}$ at $30^{\circ} \mathrm{C}$. The surface was then washed with distilled water to remove unbound glutaraldehyde. Finally, PVC beaker was poured with $5 \mathrm{~mL}$ of enzyme solution containing $0.245 \mathrm{mg}$ of $\mathrm{OPH}$ and kept overnight at $4^{\circ} \mathrm{C}$. Then the surface was washed with buffer to remove the unbound enzyme.

3.3. Scanning Electron Microscopy of PVC Surface. The morphology of PVC beaker surface before and after the immobilization of enzyme was studied by SEM analysis. The change on the chemically activated PVC surface (Figure 3 ) was observed after immobilization method. Such a change in surface morphology of the PVC surface after immobilization method confirms the enzyme immobilization.

3.4. Determination of Working Potential of the OPH Biosensor. The amperometric determination of OP pesticides by OPHbased biosensor depends on the anodic detection of 4nitrophenol (enzymatically liberated product) by the electrode [19]. The working electrode showed a well-defined oxidation peak at a potential of $+0.8 \mathrm{~V}$ (Figure 4). Therefore, $+0.8 \mathrm{~V}$ was selected as the working potential for the further studies.

\subsection{Kinetic Study of the OPH Biosensor}

3.5.1. Effect of $p H$. The effect of $\mathrm{pH}$ on the biosensor response in $0.1 \mathrm{M}$ succinate buffer ( $\mathrm{pH} 6.0,6.5$, and 7.0 ), sodium phosphate buffer $(7.5,8.0$, and 8.5), and borate buffer ( $\mathrm{pH} 9.0$, 9.5 , and 10.0) in 6.0-10.0 range was studied. The optimum $\mathrm{pH}$ for present method was 8.0 (Figure 5) which is higher than $\mathrm{pH}-7.4[19,23,30,31], \mathrm{pH} 7.0[32,33]$, and lower than $\mathrm{pH} 8.8$ [34] and $\mathrm{pH} 9.5$ [17]. This $\mathrm{pH}$ is similar to those reported in previous study [35].

3.5.2. Effect of Incubation Temperature. The effect of the temperature on the biosensor response from $20^{\circ} \mathrm{C}$ to $60^{\circ} \mathrm{C}$ at a regular increase of $5^{\circ} \mathrm{C}$ was also investigated. The optimum temperature for present method was $40^{\circ} \mathrm{C}$ (Figure 6). The microenvironment provided by support used for immobilization makes it thermally stable and maintains its biological activity.

3.5.3. Effect of Time of Incubation. Time of incubation was also studied from $5 \mathrm{~min}$ to $20 \mathrm{~min}$ at a regular increase of $5 \mathrm{~min}$. The response of the OPH biosensor was increased up to $10 \mathrm{~min}$ after which no increase in response was observed. The optimum incubation time for present method was $10 \mathrm{~min}$ (Figure 7).

3.5.4. Effect of Substrate Concentration. The effect of methyl parathion concentration on the response of present biosensor was studied up to $500 \mu \mathrm{M}$ at an interval of $50 \mu \mathrm{M}$. The present method showed a hyperbolic relationship between its response and methyl parathion concentration up to a final concentration of $400 \mu \mathrm{M}$ (Figure 8) after which no significant improvement in response was observed. Up to a 


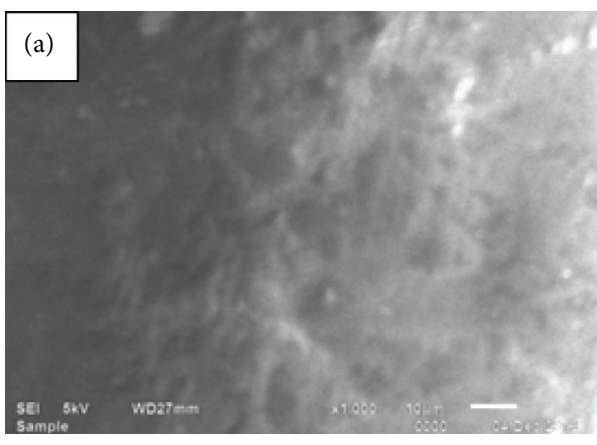

(a)

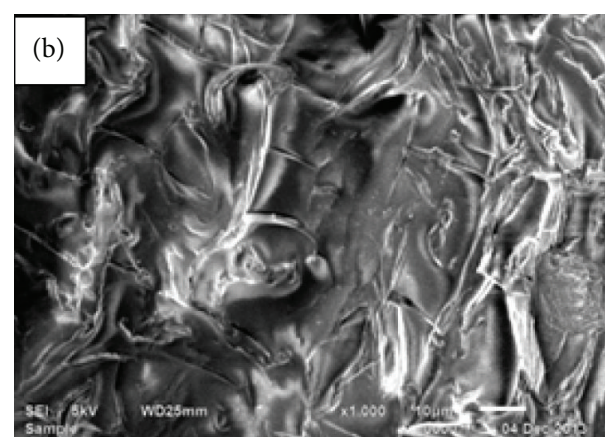

(b)

FIGURE 3: Scanning electron micrographs of a chemically modified PVC surface without (a) and with (b) immobilized enzyme.

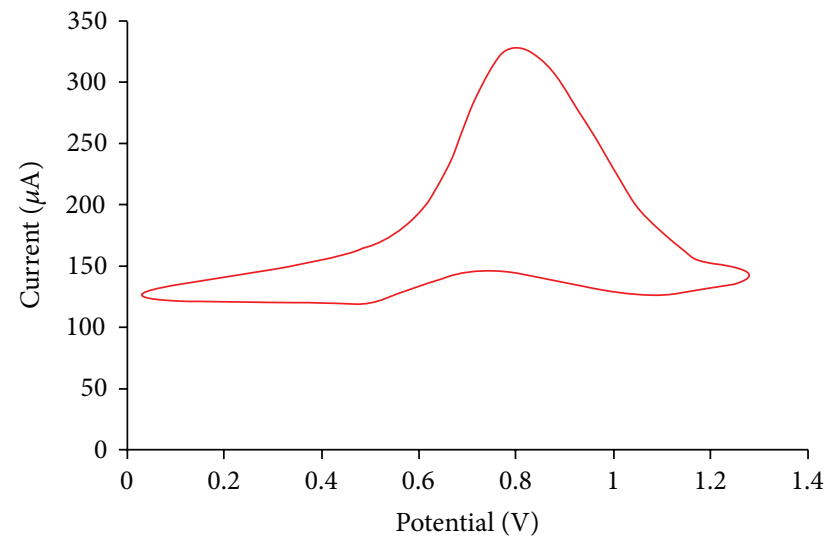

FIGURE 4: Working electrode showing oxidation peak.

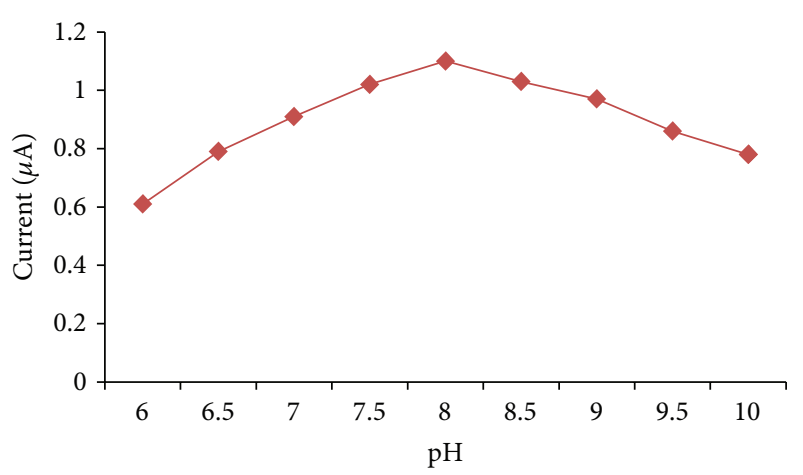

FIGURE 5: Effect of $\mathrm{pH}$ on the response of OPH biosensor.

concentration of $400 \mu \mathrm{M}$, the $\mathrm{OPH}$ biosensor showed a good response to methyl parathion.

3.5.5. $K_{m}$ and $I_{\max }$. $K_{m}$ and $I_{\max }$ were determined by calculating the slope and intercept for the reciprocal plot of current versus methyl parathion concentrations, that is, LineweaverBurk plot. Lineweaver-Burk plot between the reciprocals of methyl parathion concentration and response current for biosensor was linear. $K_{m}$ and $I_{\max }$ were $322.58 \mu \mathrm{M}$ and $1.1 \mu \mathrm{A}$ (Figure 9).

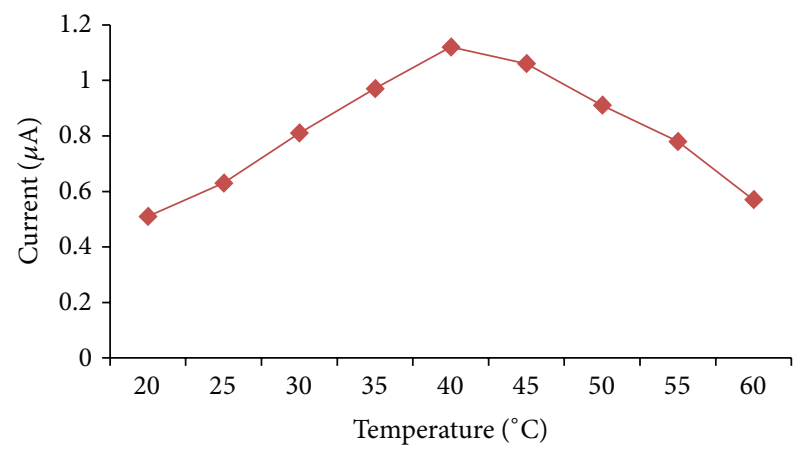

FIGURE 6: Effect of incubation temperature on the response of $\mathrm{OPH}$ biosensor.

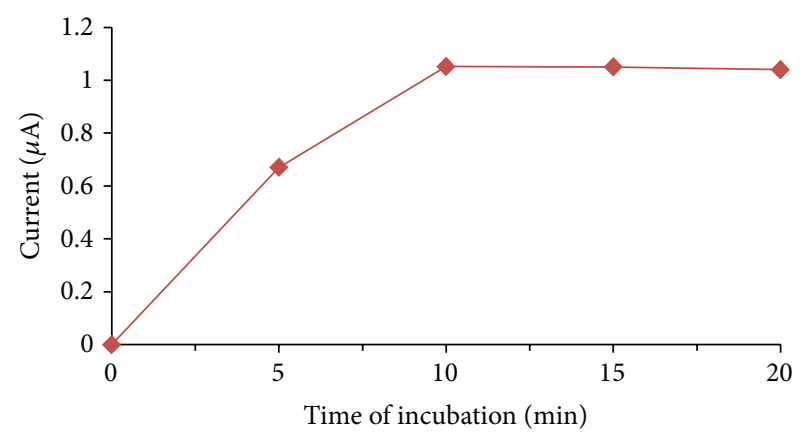

FIGURE 7: Effect of incubation time on the response of $\mathrm{OPH}$ biosensor

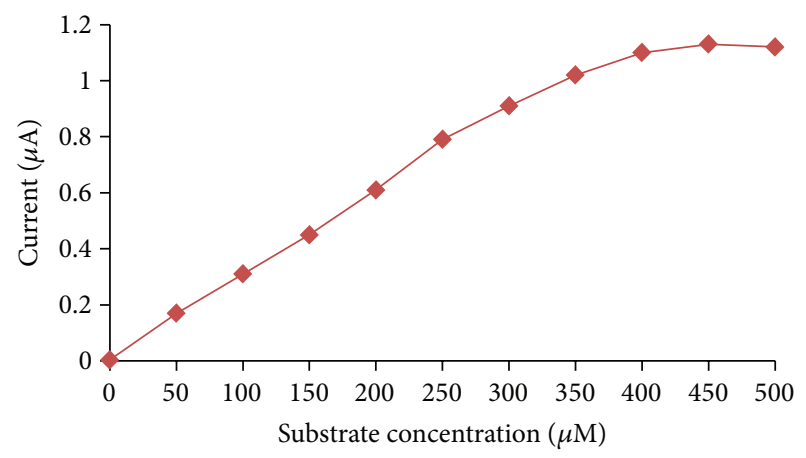

FIGURE 8: Effect of methyl parathion concentration on the present method. 


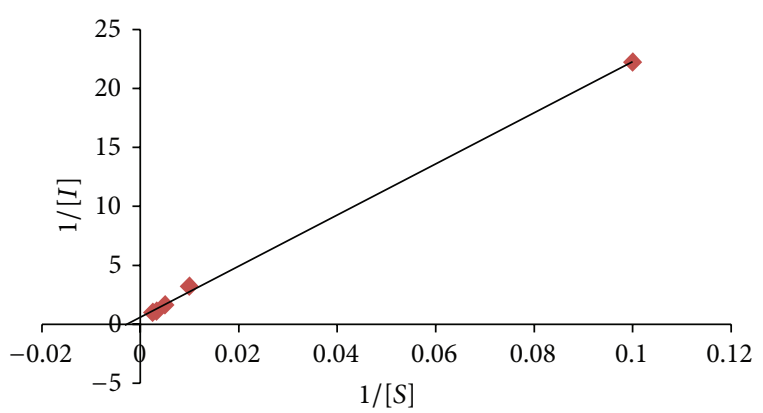

FIgURE 9: Lineweaver-Burk plot of the present method.

TABLE 1: Analytical recovery of added methyl parathion in sample.

\begin{tabular}{lcc}
\hline $\begin{array}{l}\text { Methyl parathion } \\
\text { added }(\mu \mathrm{M})\end{array}$ & $\begin{array}{c}\text { Methyl parathion } \\
\text { found }(\mu \mathrm{M}) \\
\text { mean }(n=6) \pm \mathrm{SD}\end{array}$ & \% recovery \\
\hline 5 & $4.93 \pm 0.02$ & 98.6 \\
10 & $9.91 \pm 0.02$ & 99.1 \\
\hline
\end{tabular}

TABLE 2: Within and between assay coefficients of variation for determination of OP pesticide in the samples by using the present method.

\begin{tabular}{lcc}
\hline$n$ & $\begin{array}{c}\text { OP pesticide }(\mu \mathrm{M}) \\
\text { mean } \pm \text { SD }\end{array}$ & CV (\%) \\
\hline Within batch (6) & $1.84 \pm 0.02$ & 1.58 \\
Between batch (6) & $1.83 \pm 0.03$ & 1.78 \\
\hline
\end{tabular}

\subsection{Evaluation of the Biosensor}

3.6.1. Linear Working Range and Minimum Detection Limit. The linear working range and minimum detection limit of the present biosensor were calculated from standard graph between response current and substrate concentration (methyl parathion). The linear range for methyl parathion was found to be $0.1-200 \mu \mathrm{M}$.

3.6.2. Analytical Recovery. The reliability of the present method was determined by the analytical recovery of added methyl parathion (Table 1). The mean analytical recovery of added methyl parathion $(5 \mu \mathrm{M}$ and $10 \mu \mathrm{M})$ was $98.6 \%$ and $99.1 \%$, respectively.

3.6.3. Precision. To study reproducibility of the present method, the OP pesticide level was determined in the sample repeatedly on the same day (within batch) and in the same sample after storage at $4^{\circ} \mathrm{C}$ for one week (between batch). The results of within batch and between batch coefficients of variation (CVs) were $<1.58 \%$ and $<1.78 \%$ (Table 2 ).

3.6.4. Accuracy. To study the accuracy of the present method, the levels of methyl parathion in 5 spiked water samples were determined by the standard method $(x)$ and by the present method $(y)$ (Figure 10). The result obtained by the present method was in agreement with the standard method with a correlation of 0.985 .
TABLE 3: Effect of various interfering species on response of the present method.

\begin{tabular}{lc}
\hline Compound added (final conc. $2 \mu \mathrm{M}$ ) & \% relative response \\
\hline None & 100 \\
Fructose & 99.5 \\
Glucose & 102 \\
Sucrose & 99.4 \\
$\mathrm{Zn}(\mathrm{II})$ & 98.3 \\
$\mathrm{Cu}(\mathrm{II})$ & 98.7 \\
$\mathrm{Cd}(\mathrm{II})$ & 99.2 \\
$\mathrm{Ni}(\mathrm{II})$ & 97.3 \\
$\mathrm{~Pb}(\mathrm{II})$ & 97.7 \\
\hline
\end{tabular}

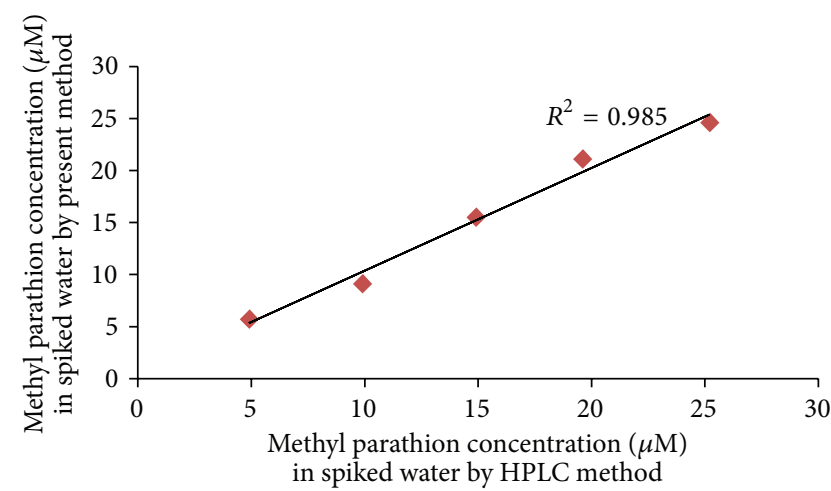

FIgURE 10: Correlation between values of methyl parathion spiked water samples determined by standard HPLC method ( $x$-axis) and by the present method ( $y$-axis).

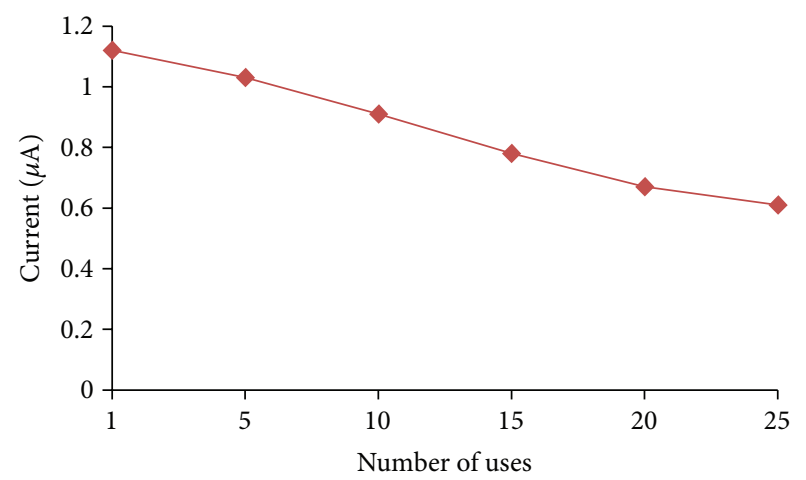

FIGURE 11: Reusability of the OPH biosensor.

3.7. Reusability and Storage Stability of OPH Biosensor. The present biosensor lost $50 \%$ of its initial activity after its 25 uses over a period of 50 days (Figures 11 and 12), when stored at $4^{\circ} \mathrm{C}$, which is better than previously reported biosensors [17, 33].

3.8. Interference Study. Among the various substances investigated for possible interference on the response of the present method, none caused any significant interference (Table 3). 


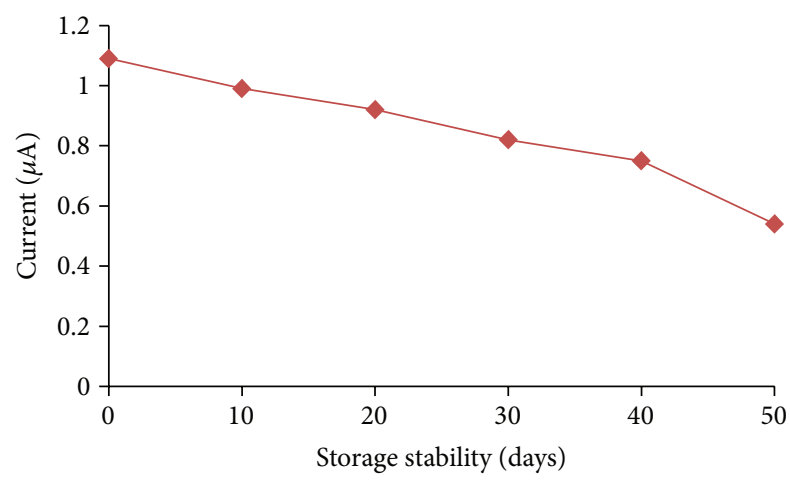

FIGURE 12: Storage stability of the OPH biosensor.

TABLE 4: OP pesticide concentration in different food samples.

\begin{tabular}{lcc}
\hline Serial number & Sample & $\begin{array}{c}\text { Concentration of OP } \\
\text { pesticide }(\mathrm{mg} / \mathrm{kg}) \\
(n=3)\end{array}$ \\
\hline 1. & Grape & 0.146 \\
2. & Apple & 0.243 \\
3. & Cauliflower & 0.031 \\
4. & Cabbage & 0.017 \\
\hline
\end{tabular}

$n$ : number of assays.

TABLE 5: OP pesticide concentration in different water samples.

\begin{tabular}{lcc}
\hline Serial number & Sample & $\begin{array}{c}\text { Concentration of OP } \\
\text { pesticide (mg/lit) } \\
(n=3)\end{array}$ \\
\hline 1. & Pond water & 0.0091 \\
2. & Canal water & 0.0037 \\
3. & Bore-well water & 0.0029 \\
\hline
\end{tabular}

$n$ : number of assays.

3.9. Application of Present Method in Determination of $O P$ Pesticides in Food and Water Samples. The OP pesticides in differed samples were determined by the newly developed biosensor. OP pesticide level in fruits and vegetables was found in the range of $0.146 \mathrm{mg} / \mathrm{kg}-0.243 \mathrm{mg} / \mathrm{kg}$ and $0.017 \mathrm{mg} / \mathrm{kg}-0.031 \mathrm{mg} / \mathrm{kg}$, respectively (Table 4 ). The OP pesticide content of water samples was also determined and found in the range $0.0029-0.0091 \mathrm{mg} / \mathrm{lit}$ (Table 5).

\section{Conclusion}

The use of carbon nanotubes as electrode material facilitates the enhanced amperometric determination of OP pesticides. The carbon nanotubes based transducer provides sensitive and stable detection of the 4-nitrophenol (enzymatically liberated product of $\mathrm{OP}$ pesticides). The use of $\mathrm{OPH}$ for biorecognition element and carbon nanotubes electrode for amperometric determination provides advantages over AChE-based biosensors that are less specific towards OP pesticides and requires multiple steps. PVC has emerged as an ideal support for enzyme immobilization and its use in designing of present electrochemical cell has proved it better than other reported biosensors. The present method provides a laboratory based analytical method for the determination of OP pesticides with high specificity. It provides fast determination of OP pesticides as well as in-field monitoring. The present method can act as a model for the development of indigenous OP pesticide sensor in miniature form.

\section{Conflict of Interests}

Authors have no conflict of interests in publishing of this research article.

\section{Acknowledgment}

The authors acknowledge the financial support provided by University Grants Commission, New Delhi, to Biosensors and Diagnostics Laboratory, Maharshi Dayanand University, Rohtak, India.

\section{References}

[1] B. K. Singh, "Organophosphorus-degrading bacteria: ecology and industrial applications," Nature Reviews Microbiology, vol. 7, no. 2, pp. 156-164, 2009.

[2] S. B. Bird, T. D. Sutherland, C. Gresham, J. Oakeshott, C. Scott, and M. Eddleston, "OpdA, a bacterial organophosphorus hydrolase, prevents lethality in rats after poisoning with highly toxic organophosphorus pesticides," Toxicology, vol. 247, no. 23, pp. 88-92, 2008.

[3] W. J. Donarski, D. P. Dumas, D. P. Heitmeyer, V. E. Lewis, and F. M. Raushel, "Structure-activity relationships in the hydrolysis of substrates by the phosphotriesterase from Pseudomonas diminuta," Biochemistry, vol. 28, no. 11, pp. 4650-4655, 1989.

[4] S. Chapalamadugu and G. R. Chaudhry, "Microbiological and biotechnological aspects of metabolism of carbamates and organophosphates," Critical Reviews in Biotechnology, vol. 12, no. 5-6, pp. 357-389, 1992.

[5] J. A. Compton, Military Chemical and Biological Agents, Telford Press, New Jersey, NJ, USA, 1988.

[6] J. Sherma, "Pesticides," Analytical Chemistry, vol. 65, no. 12, pp. 40-54, 1993.

[7] S. Yao, A. Meyer, and G. Henze, "Comparison of amperometric and UV-spectrophotometric monitoring in the HPLC analysis of pesticides," Fresenius' Journal of Analytical Chemistry, vol. 339, no. 4, pp. 207-211, 1991.

[8] S. Lacorte and D. Barceló, "Rapid degradation of fenitrothion in estuarine waters," Environmental Science and Technology, vol. 28, no. 6, pp. 1159-1163, 1994.

[9] S. Lacorte and D. Barcelo, "Determination of organophosphorus pesticides and their transformation products in river waters by automated on-line solid-phase extraction followed by thermospray liquid chromatography-mass spectrometry," Journal of Chromatography A, vol. 712, no. 1, pp. 103-112, 1995.

[10] I. Karube, K. Yano, S. Sasaki, Y. Nomura, and K. Ikebukuro, "Biosensors for environmental monitoring," Annals of the New York Academy of Sciences, vol. 864, pp. 23-36, 1998.

[11] J. Diel-Faxon, A. L. Gjindilis, P. Atanasov, and E. Wilkins, "Flow injection amperometric enzyme biosensor for direct 
determination of organophosphate nerve agents," Sensors and Actuators B, vol. 35, pp. 448-457, 1996.

[12] P. Skládal, "Biosensors based on cholinesterase for detection of pesticides," Food Technology and Biotechnology, vol. 34, no. 1, pp. 43-49, 1996.

[13] E. P. Meulenberg, W. H. Mulder, and P. G. Stoks, "Immunoassays for pesticides," Environmental Science and Technology, vol. 29, no. 3, pp. 553-561, 1995.

[14] A. Mulchandani, W. Chen, P. Mulchandani, J. Wang, and K. R. Rogers, "Biosensors for direct determination of organophosphate pesticides," Biosensors and Bioelectronics, vol. 16, no. 4-5, pp. 225-230, 2001.

[15] K. R. Rogers and C. L. Gerlach, "Environmental biosensors: a status report," Environmental Science and Technology, vol. 30, pp. 486A-491A, 1996.

[16] I. Palchetti, A. Cagnini, M. del Carlo, C. Coppi, M. Mascini, and A. P. F. Turner, "Determination of anticholinesterase pesticides in real samples using a disposable biosensor," Analytica Chimica Acta, vol. 337, no. 3, pp. 315-321, 1997.

[17] P. Mulchandani, W. Chen, and A. Mulchandani, "Flow injection amperometric enzyme biosensor for direct determination of organophosphate nerve agents," Environmental Science and Technology, vol. 35, no. 12, pp. 2562-2565, 2001.

[18] D. P. Dumas, S. R. Caldwell, J. R. Wild, and F. M. Raushel, "Purification and properties of the phosphotriesterase from Pseudomonas diminuta," The Journal of Biological Chemistry, vol. 264, no. 33, pp. 19659-19665, 1989.

[19] A. Mulchandani, "Amperometric thick-film strip electrodes for monitoring organophosphate nerve agents based on immobilized organophosphorus hydrolase," Analytical Chemistry, vol. 71, no. 11, pp. 2246-2249, 1999.

[20] N. Jaffrezic-Renault, "New trends in biosensors for organophosphorus pesticides," Sensors, vol. 1, no. 2, pp. 60-74, 2001.

[21] B. Prieto-Simón, M. Campàs, S. Andreescu, and J.-L. Marty, "Trends in flow-based biosensing systems for pesticide assessment," Sensors, vol. 6, no. 10, pp. 1161-1186, 2006.

[22] J. Wang, "Carbon-nanotube based electrochemical biosensors: a review," Electroanalysis, vol. 17, no. 1, pp. 7-14, 2005.

[23] R. P. Deo, J. Wang, I. Block et al., "Determination of organophosphate pesticides at a carbon nanotube/organophosphorus hydrolase electrochemical biosensor," Analytica Chimica Acta, vol. 530, no. 2, pp. 185-189, 2005.

[24] D. Herzlinger, P. Viitanen, N. Carrasco, and H. R. Kaback, "Monoclonal antibodies against the lac carrier protein from Escherichia coli. 2. Binding studies with membrane vesicles and proteoliposomes reconstituted with purified lac carrier protein," Biochemistry, vol. 23, no. 16, pp. 3688-3693, 1984.

[25] T. G. Bernhardt and P. A. J. de Boer, "The Escherichia coli amidase AmiC is a periplasmic septal ring component exported via the twin-arginine transport pathway," Molecular Microbiology, vol. 48, no. 5, pp. 1171-1182, 2003.

[26] Y.-H. Liu, Z.-S. Chen, J. Lian, X. Huang, and Y.-C. Chung, "Purification and characterization of a novel organophosphorus pesticide hydrolase from Penicillium lilacinum BP303," Enzyme and Microbial Technology, vol. 34, no. 3-4, pp. 297-303, 2004.

[27] G. R. Chaudhry, A. N. Ali, and W. B. Wheeler, "Isolation of a methyl parathion-degrading Pseudomonas sp. that possesses DNA homologous to the opd gene from a Flavobacterium sp," Applied and Environmental Microbiology, vol. 54, no. 2, pp. 288$293,1988$.
[28] O. H. Lowry, N. J. Rosebrough, A. L. Farr, and R. J. Randall, "Protein measurement with the Folin phenol reagent," The Journal of Biological Chemistry, vol. 193, no. 1, pp. 265-275, 1951.

[29] V. Hooda, A. Gahlaut, H. Kumar, and C. S. Pundir, "Biosensor based on enzyme coupled PVC reaction cell for electrochemical measurement of serum total cholesterol," Sensors and Actuators B: Chemical, vol. 136, no. 1, pp. 235-241, 2009.

[30] J. H. Lee, J. Y. Park, K. Min, H. J. Cha, S. S. Choi, and Y. J. Yoo, "A novel organophosphorus hydrolase-based biosensor using mesoporous carbons and carbon black for the detection of organophosphate nerve agents," Biosensors and Bioelectronics, vol. 25, no. 7, pp. 1566-1570, 2010.

[31] J. Wang, L. Chen, A. Mulchandani, P. Mulchandani, and W. Chen, "Remote biosensor for in-situ monitoring of organophosphate nerve agents," Electroanalysis, vol. 11, no. 12, pp. 866-869, 1999.

[32] S. H. Chough, A. Mulchandani, P. Mulchandani, W. Chen, J. Wang, and K. R. Rogers, "Organophosphorus hydrolase-based amperometric sensor: modulation of sensitivity and substrate selectivity," Electroanalysis, vol. 14, no. 4, pp. 273-276, 2002.

[33] J. Wang, R. Krause, K. Block, M. Musameh, A. Mulchandani, and M. J. Schöning, "Flow injection amperometric detection of OP nerve agents based on an organophosphorus-hydrolase biosensor detector," Biosensors and Bioelectronics, vol. 18, no. 23, pp. 255-260, 2003.

[34] V. Sacks, I. Eshkenazi, T. Neufeld, C. Dosoretz, and J. Rishpon, "Immobilized parathion hydrolase: an amperometric sensor for parathion," Analytical Chemistry, vol. 72, no. 9, pp. 2055-2058, 2000.

[35] T. Laothanachareon, V. Champreda, P. Sritongkham, M. Somasundrum, and W. Surareungchai, "Cross-linked enzyme crystals of organophosphate hydrolase for electrochemical detection of organophosphorus compounds," World Journal of Microbiology and Biotechnology, vol. 24, no. 12, pp. 3049-3055, 2008. 

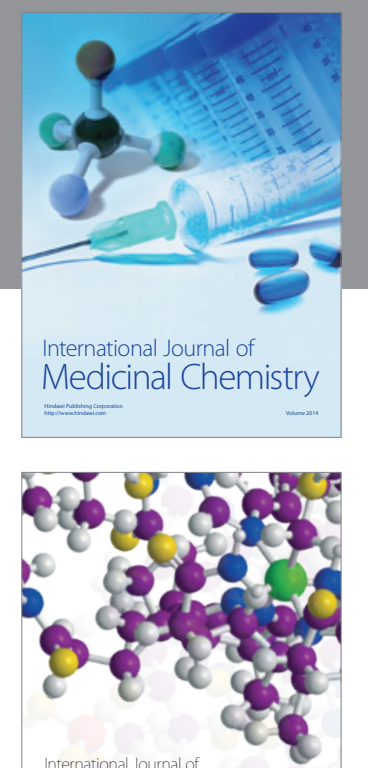

\section{Carbohydrate} Chemistry

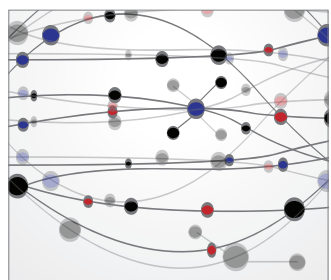

The Scientific World Journal
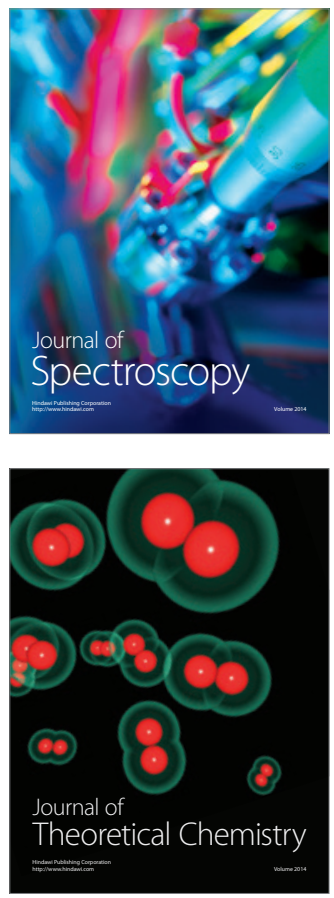
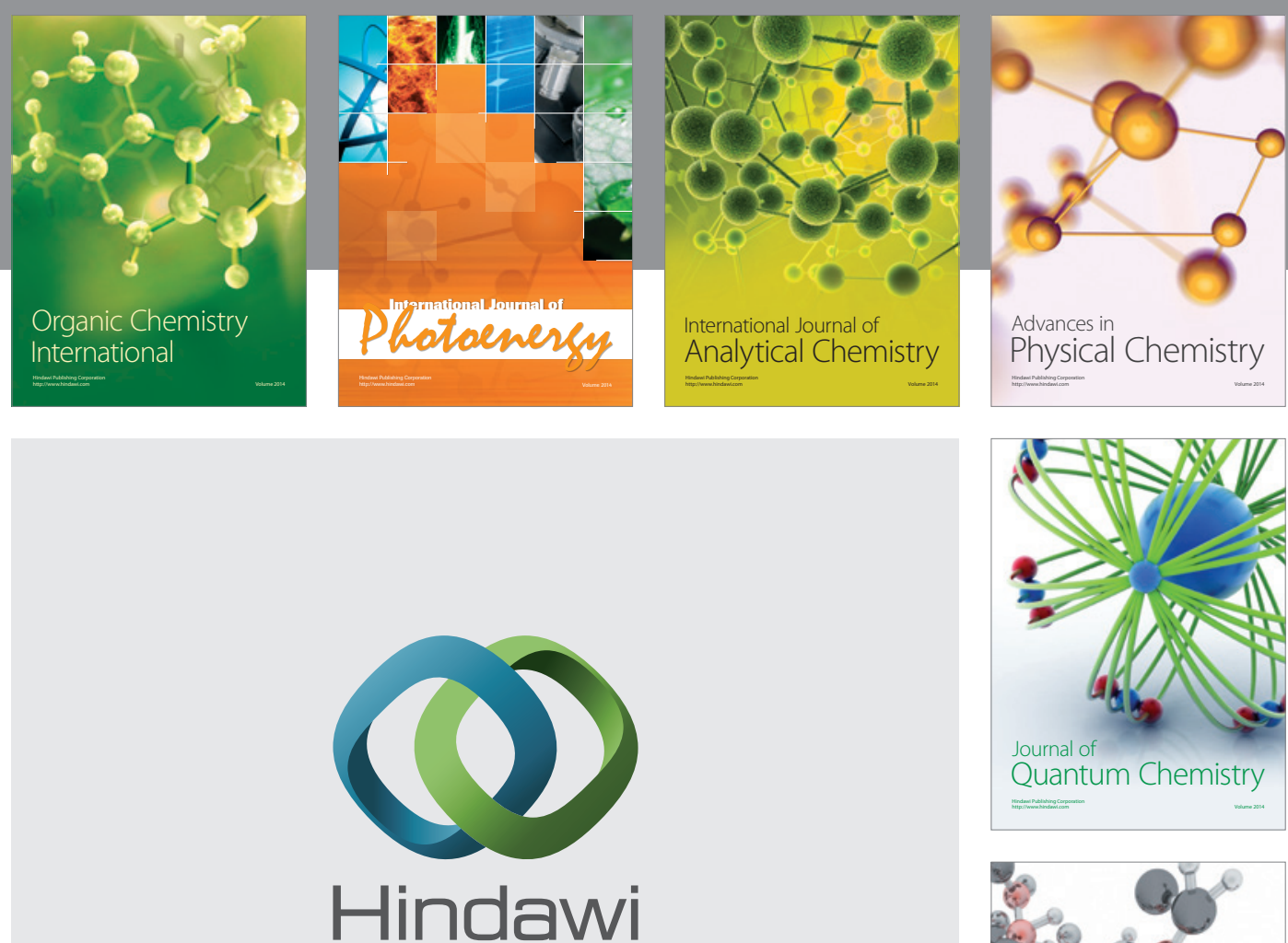

Submit your manuscripts at

http://www.hindawi.com

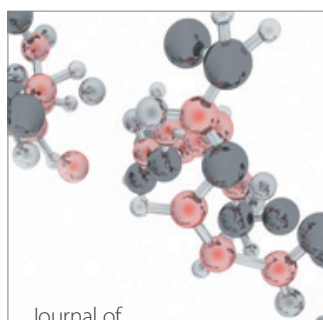

Analytical Methods

in Chemistry

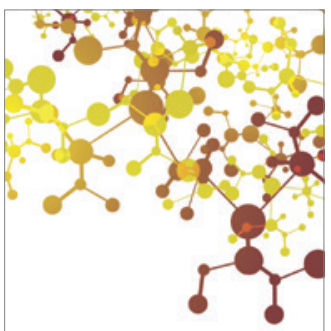

Journal of

Applied Chemistry

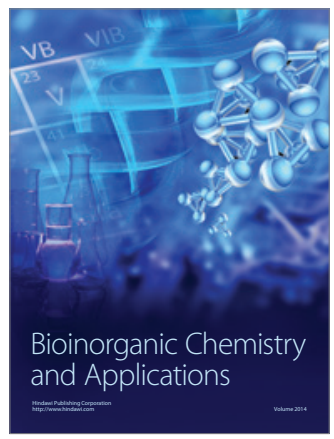

Inorganic Chemistry
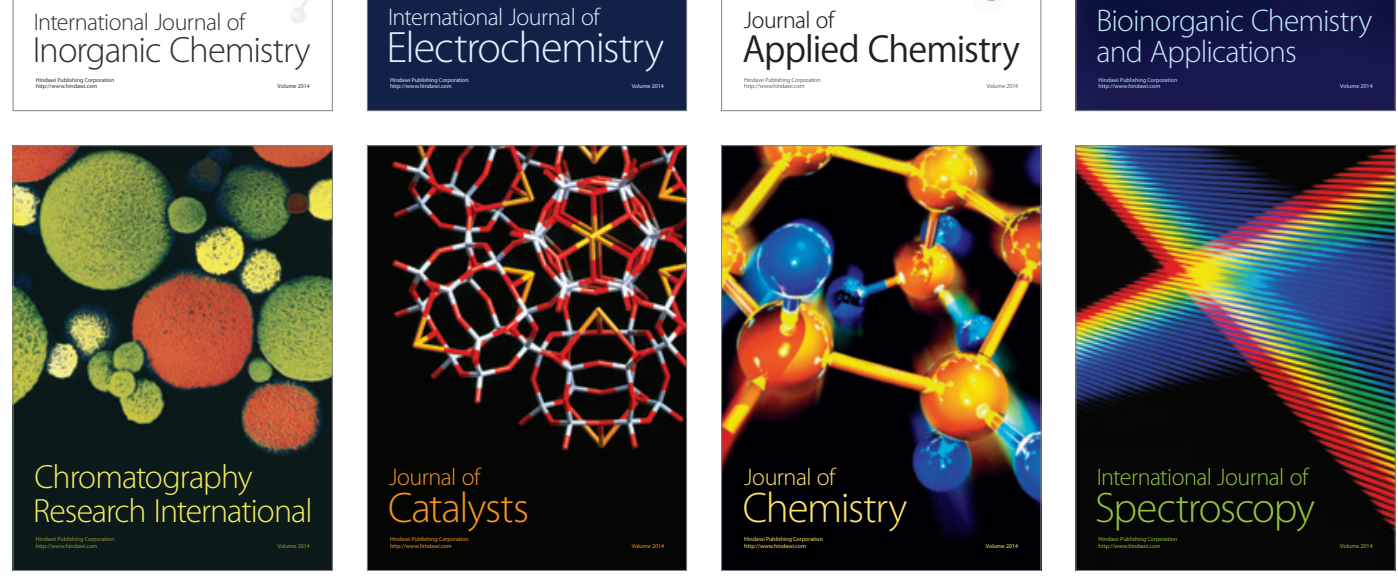